Gut, 1986, 27, 428-432

\title{
Effect of cimetidine and pirenzepine in combination on 24 hour intragastric acidity in subjects with previous duodenal ulceration
}

\author{
J G WILliAMS, M DEAKIN, AND J K RAMAGE \\ From the Department of Gastroenterology, RN Hospital Haslar, Gosport, Hampshire
}

SUMMARY Intragastric $\mathrm{pH}$ was monitored during 24 hours in eight volunteers with duodenal ulcer disease in remission, while on placebo, cimetidine $400 \mathrm{mg}$ bd, pirenzepine $50 \mathrm{mg}$ bd, cimetidine $400 \mathrm{mg}$ bd + pirenzepine $50 \mathrm{mg}$ bd, cimetidine $200 \mathrm{mg}$ bd + pirenzepine $25 \mathrm{mg}$ bd. The control of intragastric acidity during the 24 hour period by the combination of low dose cimetidine and pirenzepine was significantly better than with cimetidine, or pirenzepine alone in full dosage. This difference was most apparent after breakfast but was still present after lunch when cimetidine had no significant effect. Combination treatment is a logical approach when continuous control of intragastric acidity is needed, but a three times daily regimen will be necessary to cover the 24 hours.

Pirenzepine is known to inhibit gastric acid secretion induced by a variety of stimuli, including pentagastrin, ${ }^{1}$ insulin, ${ }^{12}$ sham-feeding ${ }^{3}$ and a peptone meal. ${ }^{4}$ Pirenzepine is thought to inhibit selectively the type I muscarinic receptor located in vagal ganglia. ${ }^{5}$ Cimetidine, however, inhibits gastric acid secretion by antagonism of parietal cell $\mathrm{H} 2$ receptors. ${ }^{6}$ Combined administration of the two drugs might therefore be expected to result in a greater degree of acid inhibition than with either alone. Londong et $_{\text {al }}{ }^{4}$ demonstrated this effect after intravenous administration of the drugs using in vivo titration and a peptone meal stimulus. As the therapeutic effect of cimetidine and pirenzepine in combination is being assessed in the treatment of duodenal ulcer in clinical trial we considered it important to evaluate the effects on intragastric acidity throughout a 24 hour period using conventional oral dosages.

\section{Methods}

\section{SUBJECTS}

Eight male volunteers (age range $28-42$ years) were studied. Each had a history of duodenal ulcer diagnosed by endoscopy but was symptomatically in

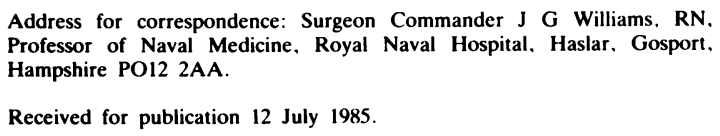

Address for correspondence: Surgeon Commander J G Williams. RN, Professor of Naval Medicine, Royal Naval Hospital, Haslar, Gosport, Hampshire PO12 2AA.

Received for publication 12 July 1985 .

remission. The length of history of duodenal ulcer was between 18 months and 11 years. None of the volunteers had coexisting medical illness, or was taking medication.

Each, volunteer was studied on five separate occasions at least one week apart. Each study day started at 0730 hours, after an overnight fast, and lasted for 24 hours. Between 0730 and 0745 hours a $10 \mathrm{~F}$ gauge Salem sump nasogastric tube was passed and the position checked by water recovery.

Standard meals comprising $375 \mathrm{ml}$ Clinifeed 500 together with one Oxo cube dissolved in $200 \mathrm{ml}$ hot water were taken by mouth at 0800,1300 , and 1800 hours. The timing of additional tea and cigarettes was kept constant for each individual on all study days.

Five millilitre samples of gastric juice were aspirated for $\mathrm{pH}$ measurement $(\mathrm{pHm} \mathrm{82,} \mathrm{Radiometer,}$ Copenhagen) at 15 minute intervals after meals for two hours, half hourly between meals, and hourly overnight. Aspirates taken within one hour of ingestion of the tablets were returned to the stomach to avoid aspiration of active drugs.

The treatment periods were randomised, and the study conducted in a double blind fashion using a double dummy tablet technique. Tablets were given at 2300 hours on the night before each study and at 0800 and 2300 hours on the study days.

Blood samples were taken before and after each study period for full blood count, plasma urea and 


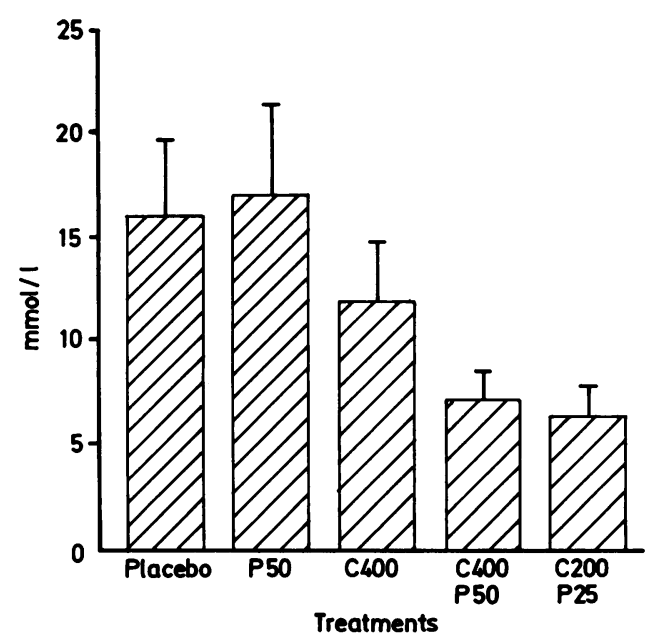

Fig. 1 Mean hourly 24 hour hydrogen ion activity for each treatment group. (P50=pirenzepine $50 \mathrm{mg}$ bd, $C 400=$ cimetidine $400 \mathrm{mg}$ bd, C400 P50=cimetidine $400 \mathrm{mg}+$ pirenzepine $50 \mathrm{mg}$ bd; C200 P25=cimetidine $200 \mathrm{mg}+$ pirenzepine $25 \mathrm{mg}$ bd; mean $\pm S E M, n=8$ ).

electrolytes, and serum bilirubin, aspartate transferase, gamma glutamyl transferase, and alkaline phosphatase.

For analysis of the data $\mathrm{pH}$ values were converted to hydrogen ion activity, and mean 24 hour values (mean of hourly readings) for each subject were compared between treatment groups. Area under the hydrogen ion activity curve was used to compare the effect of the different treatments during the four hours after meals. The Wilcoxon's rank sum test was used to test for significance, comparing by rank the data for each subject on different treatments. For descriptive purposes only the data have been displayed graphically as mean values with standard errors of the mean (SEM).

\section{Results}

Mean hourly hydrogen ion activity $(\mathrm{mmol} / \mathrm{l})$ for each treatment group over the 24 hour period has been displayed in Figure 1.

Pirenzepine alone had no significant effect on intragastric acidity and did not change the 24 hour $\mathrm{H}^{+}$activity as compared with placebo (Fig. 2). Cimetidine alone was significantly better than placebo or pirenzepine, resulting in a $26 \%$ decrease in mean hourly hydrogen ion activity $(p<0.05)$. Both high and low dose combinations produced a further lowering of intragastric acidity. The effects of both combinations were similar with the low dose combination being significantly better than either pirenzepine or cimetidine alone in twice the dosage $(p<0.05)$. The hydrogen ion activity profile for this dose has been included in Figure 2. The effect of the

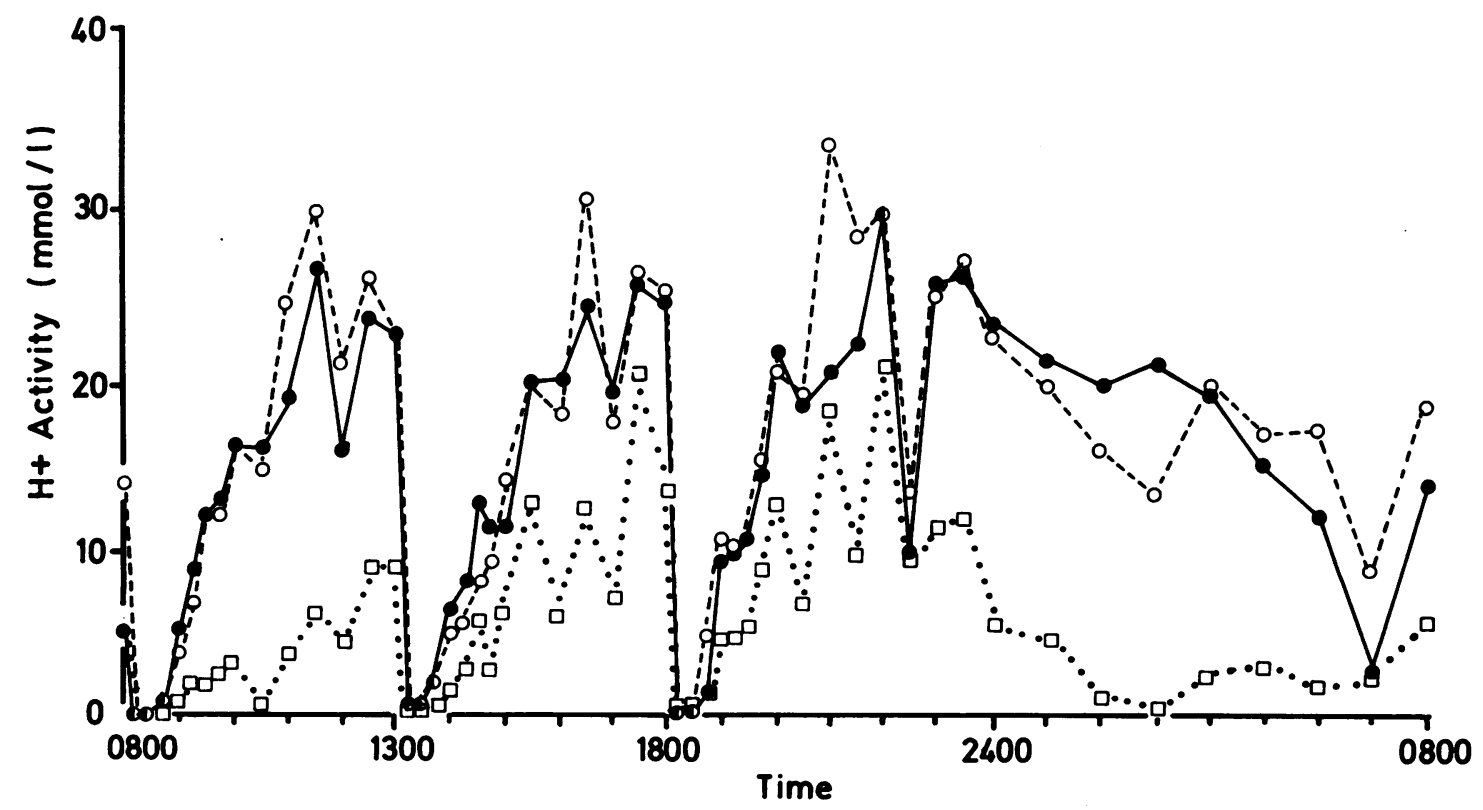

Fig. 2 Mean 24 hour hydrogen ion activity profile for placebo $(-<)$, pirenzepine $50 \mathrm{mg}$ bd $(\mathrm{O}--\mathrm{O})$ and

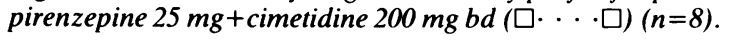




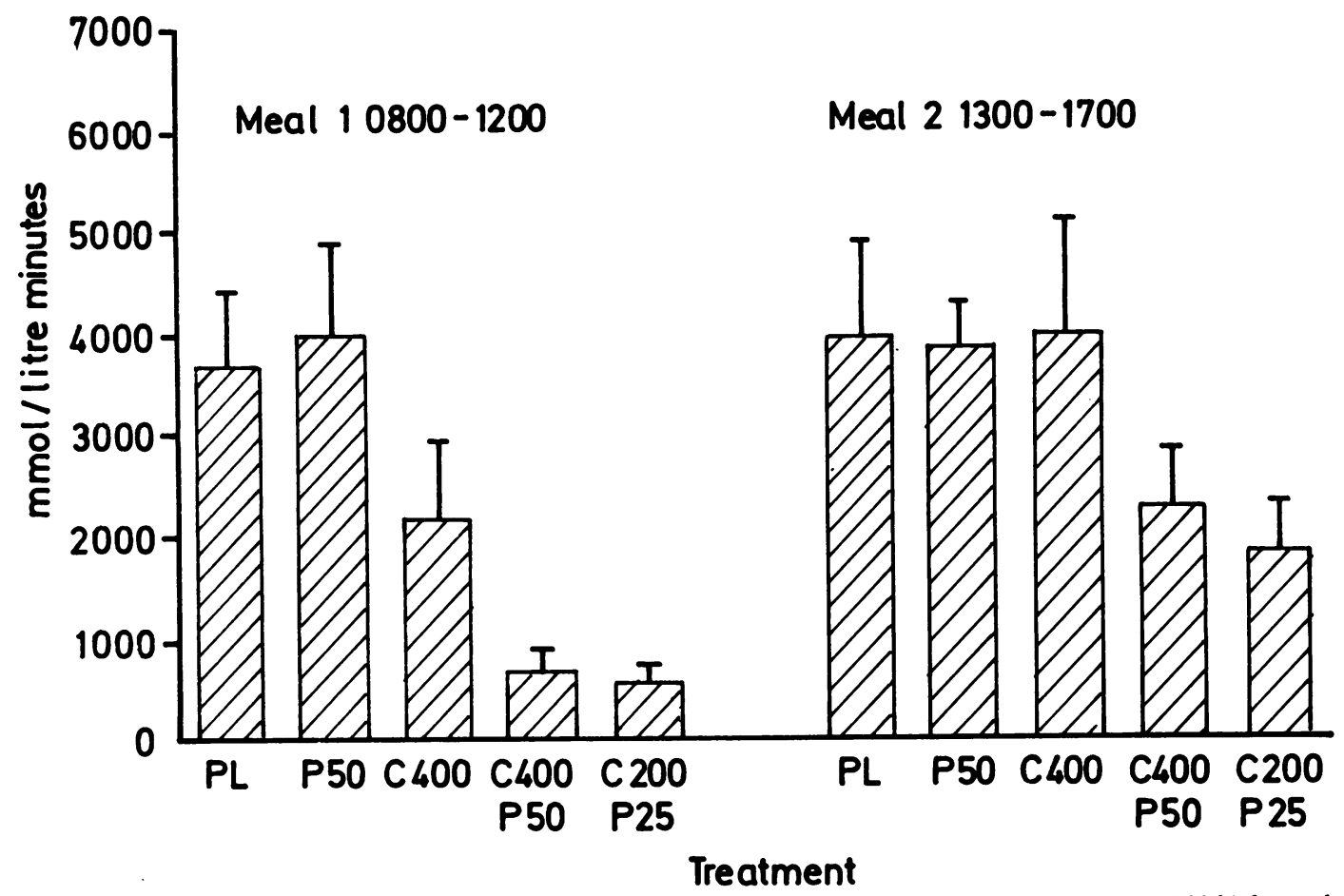

Fig. 3 Area under the hydrogen ion activity curve after breakfast $(0800$ to $1200 \mathrm{~h})$ and lunch $(1300$ to $1700 \mathrm{~h})$ for each treatment group. (mean $\pm S E M, n=8)$.

high dose combination was significantly better than pirenzepine alone but did not quite reach statistical significance when compared with cimetidine alone.

The effect of each of the regimens on the meal periods is shown as mean area under the hydrogen ion activity curve after breakfast and lunch in Figure 3. Pirenzepine alone had no demonstrable effect after either meal. Significant inhibition occurred after breakfast after cimetidine alone $(\mathrm{p}<0.05)$, but no effect was seen after lunch. Both combinations, however, were better at decreasing meal stimulated acidity than either cimetidine or pirenzepine alone after both breakfast and lunch $(\mathrm{p}<0 \cdot 01)$. Between the hours of 1700 and 2300 no drug effects were apparent. Significant inhibition of nocturnal secretion (between 2300 and 0800 ) was seen with cimetidine alone and with both drug combinations $(\mathrm{p}<0.01 v s$ placebo and pirenzepine) but no statistically significant difference was seen between cimetidine alone and the combinations (Fig. 4).

No subject complained of adverse effects during this study and no significant changes were seen on haematological or biochemical screening.

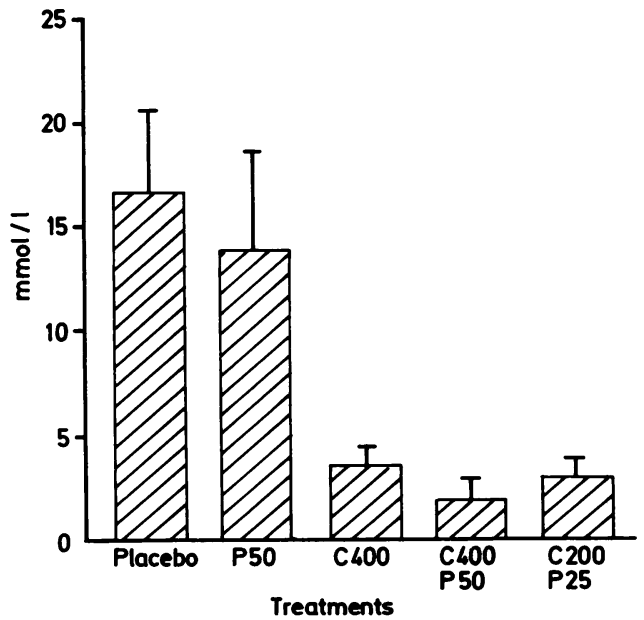

Fig. 4 Hourly nocturnal (2400-0800 h) hydrogen ion activity for each treatment group. (mean $\pm S E M, n=8)$.

\section{Discussion}

In this study we have shown that to lower intragastric acidity in subjects with previous duodenal 
ulceration cimetidine and pirenzepine given orally are more effective in combination than individually.

The method we use gives a standard reproducible meal three times a day and this technique allows comparison of effects between meals (and between other treatments in identical studies). The meal is a potent stimulus to acid secretion, requiring about $40 \mathrm{mmol} / \mathrm{h}$ of sodium bicarbonate to maintain a constant $\mathrm{pH}$ of 5.5 in in vivo titration studies in normal subjects. ${ }^{7}$

The best method of expression of data related to intragastric acidity is controversial. ${ }^{8}$ We have chosen to present the data in this study as hydrogen ion activity, although analysis of unconverted $\mathrm{pH}$ data yields the same statistical conclusions. For statistical evaluation we have used a non-parametric method of analysis as hydrogen ion activity is not normally distributed, although a paired Student's $t$ test yields unchanged conclusions.

Anticholinergic drugs given orally in acceptable doses have rarely been shown to lower intragastric acidity. ${ }^{9}$ Pirenzepine is no exception to this ${ }^{10}$ which is confirmed by our data. We have also confirmed the significant effect of cimetidine given alone, ${ }^{11}$ and shown that the two drugs given in combination produce a further decrease in hydrogen ion activity that is greater than can be expected by an additive effect, particularly as this is seen when the combination doses are halved. This synergism is most apparent after a meal stimulus and is even seen five to nine hours after drug administration, when cimetidine alone has no effect.

At night little additional benefit is seen for either combination over cimetidine alone. This is not surprising in this group of duodenal ulcer subjects who respond well to cimetidine, in contrast with a group of non-responders whose nocturnal acid output was little decreased by cimetidine alone, but showed a significant lowering on cimetidine $1 \mathrm{~g}$ daily ( $200 \mathrm{mg}$ tds, $400 \mathrm{mg}$ nocte) combined with atropine $4.8 \mathrm{mg}$ daily ( $1.2 \mathrm{mg}$ qds with food). ${ }^{12}$ A previous study ${ }^{13}$ had shown that the addition of atropine $2.4 \mathrm{mg} /$ day to cimetidine $1 \mathrm{~g} /$ day failed to reduce further 24 hour intragastric acidity in duodenal ulcer patients who had responded to cimetidine. This dose produced no side effects but the higher dose ${ }^{12}$ caused anticholinergic symptoms in all seven subjects studied, in contrast with our experience with pirenzepine where no side effects were encountered. This is in keeping with the gastro-selective (M1) anticholinergic properties of pirenzepine. ${ }^{14}$

The use of the two drugs in combination is logical in clinical situations where profound inhibition of intragastric acidity is required. ${ }^{15-19}$ Our data suggest, however, that if continuous inhibition is needed from oral treatment, a three times daily dosing schedule should be used. Intravenous ranitidine and pirenzepine in combination have been shown to produce a more profound inhibition of peptone stimulated secretion than cimetidine and pirenzepine ${ }^{20}$ but the duration of this effect has not yet been reported.

\section{References}

1 Bianchi-Porro G, Prada A, Petrillo M. Inhibition of pentagastrin and insulin-stimulated gastric secretion by pirenzepine in healthy and duodenal ulcer subjects. Scand J Gastroenterol 1979; 14: suppl. 57: 63-7.

2 El-Sabbagh HN, Prinze RA, Welbourn RB, Baron JH. Influence of intravenous pirenzepine, a selective anticholinergic agent, in patients with Zollinger-Ellison syndrome. Scand J Gastroenterol 1980; 15: suppl 66: 73-7.

3 Konturek SJ, Obtulowicz W, Kwiecien N et al. Effects of pirenzepine and atropine on gastric secretory and plasma hormonal responses to sham-feeding in patients with duodenal ulcer. Scand J Gastroenterol 1980; 15: suppl 66: 63-9.

4 Londong W, Londong V. Prechtl R, Weber TH, von Werder $\mathrm{K}$. Interactions of cimetidine and pirenzepine on peptone-stimulated gastric acid secretion in man. Scand J Gastroenterol 1981; 15: suppl 66: 103-14.

5 Hammer R. Muscarinic receptors in the stomach. Scand J Gastroenterol 1980; 15: suppl 66: 5-11.

6 Black JW, Duncan WAM, Durrant DJ, Ganellin CR, Parsons ME. Definition and antagonism of histamine $\mathrm{H}_{2}$ receptors. Nature $1972 ; 236$ : 385-90.

7 Williams JG, Robertson RJ, Milton-Thompson GJ. Inhibition of food stimulated acid secretion by fenoctimine, a new antisecretory agent. Br J Clin Pharmacoi 1983; 15: 673-6.

8 Lucas M. pH or hydrogen ion concentration in statistics? Lancet 1977; 2: 826.

9 Ivey KJ. Anticholinergics: do they work in peptic ulcer? Gastroenterology 1975; 68: 154-66.

10 Etienne A, Fimmel CJ, Bron BA, Loizeau E, Blum AL. Evaluation of pirenzepine on gastric acidity in healthy volunteers using ambulatory 24 hour intragastric pH monitoring. Gut 1985; 26: 241-5.

11 Pounder RE, Williams JG, Milton-Thompson GJ, Misiewicz JJ. $24 \mathrm{hr}$ control of intragastric acidity by cimetidine in duodenal ulcer patients. Lancet 1975; 2: 1069-72.

12 Gledhill T, Buck M, Hunt RH. Effect of no treatment, cimetidine $1 \mathrm{~g} /$ day, cimetidine $2 \mathrm{~g} /$ day and cimetidine combined with atropine on nocturnal gastric secretion in cimetidine non-responders. Gut 1984; 25: 1211-6.

13 Pounder RE, Hunt RH, Vincent SH, MiltonThompson GJ. Twenty four hour intragastric acidity and nocturnal acid secretion in patients with duodenal ulcer during oral administration of cimetidine and atropine. Gut 1977; 18: 85-90.

14 Feldman M. Inhibition of gastric acid secretion by selective and nonselective anticholinergics. Gastroenterology 1984; 86: 361-6. 
15 Bonfils S, Mignon M, Danne O, Maria J. Efficacité de traitments anti-sécrétoires combinés (cimétidine et pirenzépin) dans la syndrome de Zollinger-Ellison. Nouv Presse Med 1977; 6: 3544-5.

16 Collen MJ, Pandol SJ, Raufman J-P et al. Beneficial effects of pirenzepine, a selective anticholinergic agent, in patients with Zollinger-Ellison syndrome. Gastroenterology 1982; 83: 1035.

17 Engelhardt D, Karl R, Inthorn D, Holzel D. Cimetidine-pirenzepine versus antacid for stress bleeding prophylaxis in intensive care patients. Inten Care Med 1983; 9: 243.

18 Londong W, Hasford J, Sander R et al. Prophylaxis of recurrent bleeding from gastroduodenal lesions by combination of cimetidine and pirenzepine - a double blind and multicentre trial. Scand J Gastroenterol 1982; 17: suppl 78: 840 .

19 Mignon M, Vallot T, Galmiche JP, Dupas JL, Bonfils S. Interest of a combined antisecretory treatment, cimetidine and pirenzepine in the management of severe forms of Zollinger-Ellison syndrome. Digestion 1980; 20: 56-61.

20 Londong W, Londong V, Ruthe C, Wiezert P. Complete inhibition of food-stimulated gastric acid secretion by combined application of pirenzepine and ranitidine. Gut 1981; 22: 542-8. 